\title{
A Checklist of Ants (Hymenoptera: Formicidae) of Saskatchewan
}

\author{
James R. N. Glasier ${ }^{1,5}$, SCOtt Nielsen ${ }^{2}$, John H. ACORN ${ }^{2}$, LeOnid H. Borysenko ${ }^{3}$, and Troy RADTKE ${ }^{4}$ \\ ${ }^{1}$ Evolution and Ecology Research Centre, School of Biological, Earth and Environmental Sciences, University of New South \\ Wales, Sydney, New South Wales 2052 Australia \\ ${ }^{2}$ Department of Renewable Resources, University of Alberta, Edmonton, Alberta T6G 2H1 Canada \\ ${ }^{3}$ Canadian National Collection of Insects, Arachnids and Nematodes, K. W. Neatby Building, 960 Carling Avenue, Ottawa, \\ Ontario K1A 0C6 Canada \\ ${ }^{4}$ Department of Biology, University of Regina, Regina, Saskatchewan S4S 0A2 Canada \\ ${ }^{5}$ Corresponding author: j.glasier@student.unsw.edu.au
} Glasier, James R. N., Scott Nielsen, John H. Acorn, Leonid H. Borysenko, and Troy Radtke. 2016. A checklist of ants (Hymenop-
tera: Formicidae) of Saskatchewan. Canadian Field-Naturalist 130(1): 40-48.

Based on field surveys, museum specimens, and published literature, we document 73 ant species in three subfamilies and 12 genera for the province of Saskatchewan, Canada. An additional 16 species are known from surrounding regions and are likely to occur in Saskatchewan.

Key Words: Ants; Saskatchewan; checklist; Hymenoptera; Formicidae

\section{Introduction}

The ant fauna of Saskatchewan, Canada, has been relatively poorly studied, and, thus, we present a list of ant species from the province based on our own field surveys, examination of museum specimens, and a search of the literature. Additional species that are anticipated in Saskatchewan based on their presence in surrounding regions are also noted.

Few published papers provide species-level information on ants from Saskatchewan. Kidd and Longair (1997) examined boreal ants, identifying five species. Both Radtke et al. (2014) and Glasier and Acorn (2014) examined grassland ants and listed 13 and 33 species, respectively. Several ecological studies (Ferguson 2000, 2001, 2004; Chikoski et al. 2006) have dealt with ants in Saskatchewan, but they did not identify them to species. Hansen and Klotz (2005) reviewed Camponotus species from North America and listed five species for the province, but did not provide specimen localities. Likewise, Wheeler and Wheeler (1986) mention Formica planipilis from Saskatchewan, but do not provide a locality. In their taxonomic reviews of Lasius, Wilson (1955) and Wing (1968), report seven Lasius species from southern Saskatchewan locations. In addition, Francoeur's (1973) review of fusca-group Formica reported three species in the province. With this patchwork of studies, it is difficult to assess the diversity of ants found in the province.

Ant fauna from the regions bordering Saskatchewan, however, are relatively well reported. A preliminary checklist (Wheeler et al. 1989) of ants in Manitoba (to the east) identifies 52 species, while a key for Alberta (to the west) lists 93 species (Glasier et al. 2013). Ant lists from the southern bordering states of Montana
(Wheeler and Wheeler 1988) and North Dakota (Wheeler and Wheeler 1977) identified 76 and 87 species, respectively. It may be expected that Saskatchewan would share similar ant species diversity as that reported in the surrounding regions. However, little is known about the ant fauna of the Northwest Territories and Nunavut to the north.

\section{Study Area}

Saskatchewan's surface area is $651900 \mathrm{~km}^{2}$, and the province includes four main ecozones: prairie, boreal plains, boreal shield, and taiga shield (Figure 1). The ecozones differ as follows.

The prairie ecozone is characterized by mixed grasslands to the south and aspen parkland in the north. The southern grasslands are dominated by wheatgrasses and speargrasses, with wetter areas hosting small shrubs, such as Wolf-willow (Elaeagnus commutata Bernhardi ex Rydberg) or Snowberry (Symphoricarpos spp. Duhamel). The northerly aspen parkland is dominated by fescue grasslands and aspen woodlands. The Cypress Hills, along the southwestern edge of the province, are also found in this ecozone. This is the only area of the province that remained unglaciated during the last ice age, and because of its elevation, it is covered in Lodgepole Pine (Pinus contorta Douglas ex Loudon), aspen (Populus spp. L), and White Spruce (Picea glauca (Moench) Voss) forests (Saskatchewan Conservation Data Centre 2014).

The boreal plain ecozone is a mix of boreal forest, farmland, and peatlands. In the southern areas, aspen forests dominate, with some White Spruce (Picea glauca (Moench) Voss) or Black Spruce (Picea mariana (Miller) Britton, Sterns \& Poggenburgh). Northward in this zone, peatlands with Tamarack (Larix laricina $(\mathrm{Du}$

A contribution towards the cost of this publication has been provided by the Thomas Manning Memorial Fund of the Ottawa Field-Naturalist's Club. 


\section{Legend}

- Ant locales

Ecozones
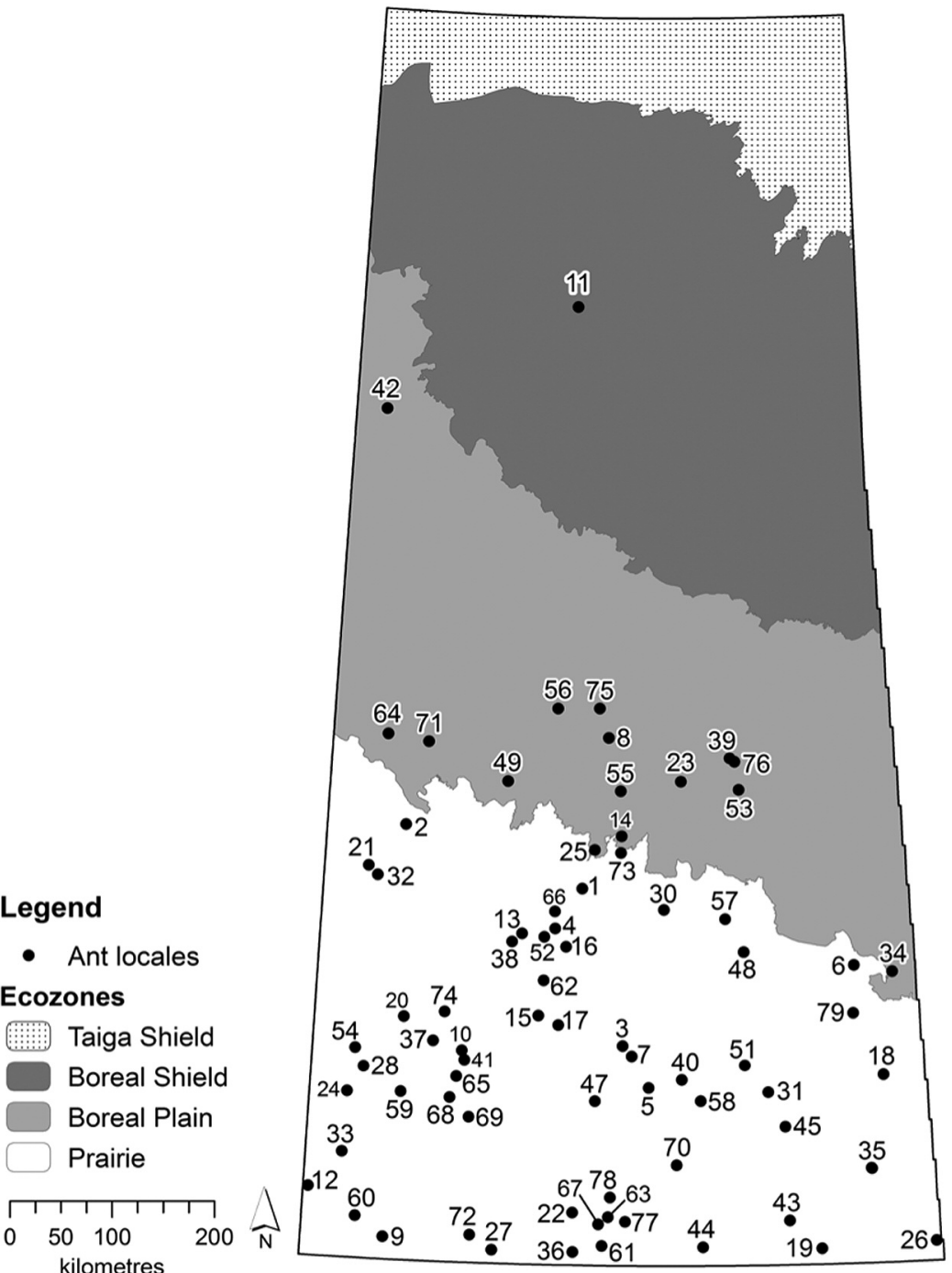

FIGURE 1: Sampled localities in Saskatchewan. Locality numbers are matched with species records in the checklist of ants.

Roi) K. Koch) and Black Spruce are common in lowlying areas, whereas elevated areas are dominated by mixed aspen and White Spruce forests. Jack Pine (Pinus banksiana Lambert) and spruce woodlands are sporadic, and found in areas with sandy soils (Saskatchewan Conservation Data Centre 2014).

The boreal shield ecozone is covered in numerous freshwater lakes. It is vegetated by a mix of Jack Pine and Black Spruce in sandy soil areas. In wet, low-lying areas, Tamarack and Black Spruce peatlands are common, while White Birch (Betula papyrifera Marshall) and Black Spruce forests are found in drier areas (Saskatchewan Conservation Data Centre 2014).

The taiga shield ecozone encompasses the northern part of Saskatchewan. It is an area of thin soils over
Precambrian bedrock and is considered transitional between boreal and tundra zones. Lowland woodlands are composed of Jack Pine, Black Spruce, and sporadic White Spruce stands. At higher elevations and further north, boreal forest transitions to tundra of mostly short Black Spruce woodlands with lichen understory (Saskatchewan Conservation Data Centre 2014).

\section{Methods}

There are few collections of ants in Saskatchewan, and we were able to examine only the holdings at the University of Saskatchewan (UofSASK; specimens collected in the 1950s). A set of specimens in vials, awaiting pinning and identification at the Agriculture and Agri-Food Canada Research Station, Saskatoon, 
was not examined. Neither the University of Regina nor the Royal Saskatchewan Museum insect collections contained any known ant collections.

Collections of Saskatchewan ants housed outside Saskatchewan included those at the University of Alberta, the University of Calgary, the Royal Alberta Museum, and the Canadian National Collection of Insects, Arachnids and Nematodes. The University of Alberta's E. H. Strickland Entomological Museum (UASM) has close to 100 ants from three main localities. The University of Calgary Entomology Collection (BDCU) comprises about 70 specimens from four localities. The Royal Alberta Museum Entomology Collection (PMAE) contains ants primarily from Grasslands National Park and includes several hundred specimens. The Canadian National Collection of Insects, Arachnids and Nematodes (CNC) has 2740 ant specimens from 60 Saskatchewan localities.

In addition, we undertook two ant surveys: one at Cree Lake (Glasier and Nielsen) in 2010 and one at the Great Sand Hills (Glasier and Acorn) in 2012. Voucher specimens from these surveys have been deposited in the E. H. Strickland Museum at the University of Alberta. In total, ant species are reported from 79 localities across the province (Figure 1).

\section{Results and Discussion}

\section{Overview of the Ant Fauna}

Based on sampling, examination of the literature, and museum collections, there are 73 species of ants, from 12 genera, and three subfamilies known from Saskatchewan. An additional 16 species and five genera are expected to be found in the province, as they are present in surrounding regions. The richest genus is Formica, with 33 recorded species. Other species-rich genera include Camponotus, Lasius, and Myrmica. Of the reported 73 ant species, all are believed to be indigenous.

Comparison with surrounding regions, especially Alberta (Glasier et al. 2013), implies that 90 or more species are most likely found in the province. Additional sampling in the northern and eastern regions of Saskatchewan should be considered to better clarify ant species distributions. Focused sampling in areas of central and southern Saskatchewan, especially grasslands and forests, will probably reveal additional species not yet reported from the province. With climate change and increasing numbers of introduced ant species in Canada, it is perhaps interesting to document which species are currently known from each region so that future studies are able to use this material as a baseline for comparisons.

\section{Checklist of Ants (Hymenoptera: Formicidae) from Saskatchewan}

Species are organized alphabetically by subfamily, genera, and species. Comments on each genus, its diversity, and ecology are provided. For each species, all known localities from Saskatchewan are listed alpha- betically, along with the source of the record. If a locality is not given, we provide a short explanation of why the species is included in the list. Locality number is given before the locality name ("\#. locality") and matches the numbers in Figure 1.

SUBFAMILY DOLICHODERINAE

\section{Genus Dolichoderus}

Both Dolichoderus species listed are expected in Saskatchewan because of their presence in Eastern Canada as well as Alberta (Glasier et al. 2013; LHB, unpublished observation). Members of this genus are rather easy to identify, because of the "shelf" on their propodeum (MacKay 1993; Fisher and Cover 2007). Found most often in conifer forests, they often form long foraging lines and often farm homopterans on plants (Fisher and Cover 2007).

Dolichoderus plagiatus (Mayr) 1870 - Expected but not confirmed: found in Alberta (LHB, unpublished observation) and Manitoba (Wheeler et al. 1989).

Dolichoderus taschenbergi (Mayr) 1866 - Expected but not confirmed: found in Alberta (Glasier et al. 2013) and Manitoba (Wheeler et al. 1989).

\section{Genus Tapinoma}

Tapinoma sessile is one of the most widespread species in North America (Fisher and Cover 2007). It can sometimes be a minor pest in houses and is commonly called the Odorous House Ant because of the strong "blue cheese" or "coconut" odour they produce when crushed (Ellison et al. 2012).

Tapinoma sessile (Say) 1836 - 3. Aylesbury (CNC), 5. Buffalo Pound Provincial Park (CNC), 10. Clearwater Lake (BDCU), 11. Cree Lake (UASM), 12. Cypress Hills Interprovincial Park (CNC), 13. Delisle (BDCU), 19. Estevan (CNC), 27. Grasslands National Park (PMAE; UASM), 28. Great Sand Hills (UASM), 31. Indian Head (CNC), 38. Laura (CNC), 50. Ogema (CNC), 54. Prelate (BDCU), 59. Roadene (CNC), 63. Saint Victor (CNC), 65. Saskatchewan Landing Provincial Park (CNC), 66. Saskatoon (CNC), 67. Scout Lake (CNC), 78. Willows (CNC).

\section{SUBFAMILY FoRMICINAE}

\section{Genus Brachymyrmex}

Brachymyrmex depilis was found at the Sandy Point Campground, Alberta $\left(50.73^{\circ} \mathrm{N}, 110.07^{\circ} \mathrm{W}\right), 5.5 \mathrm{~km}$ west of the Saskatchewan border, and there is little doubt that this species will be found in Saskatchewan as well. These small, yellowish ants often farm subterranean homopterans on grass roots. Taxonomically, $B$. depilis could contain multiple different species, and more work is needed on this complex to determine whether regional differences warrant dividing it into multiple species (Fisher and Cover 2007).

Brachymyrmex depilis Emery 1893 - Expected but not confirmed; it has been found at Sandy Point Park, Alberta, along the South Saskatchewan River, $5.5 \mathrm{~km}$ 
west of the Saskatchewan border (Glasier et al. 2013; Glasier and Acorn 2014).

\section{Genus Camponotus}

Camponotus is one of the most speciose genera in North America; they are commonly referred to as carpenter ants, as most species live in dead wood (Mackay and Mackay 2002; Hansen and Klotz 2005; Fisher and Cover 2007). In Saskatchewan there are six species in three subgenera: Camponotus, Tanaemyrmex, and Myrmentoma. Saskatchewan's C. pennsylvanicus look like intermediates between $C$. pennsylvanicus and $C$. modoc, and some myrmecologists consider these two taxa conspecific; more work and examination of these species is needed (MacKay and MacKay 2002).

Camponotus herculeanus (Linnaeus) 1758 - 8. Clarine Lake (Kidd and Longair 1997), 11. Cree Lake (UASM), 49. Norbury (UofSASK), 55. Prince Albert (CNC; UofSASK), 58. Regina (UofSASK), 64. Saint Walburg (CNC), 66. Saskatoon (CNC, UofSASK), 75. Waskesiu Lake (CNC), 76. White Fox (CNC), no exact locality given (Hansen and Klotz 2005).

Camponotus modoc Wheeler W. M. 1910 - 32. Jay Lake (CNC), 71. Turtle Lake (CNC), no exact locality given (Hansen and Klotz 2005).

Camponotus nearcticus Emery 1893 - No exact locality given (Hansen and Klotz 2005).

Camponotus novaeboracensis (Fitch) 1855 - 6. Canora (CNC), 48. Mozart (CNC), 52. Pike Lake (CNC), 62. Rudy (CNC), 66. Saskatoon (UofSASK), 72. Val Marie (CNC), 79. Yorkton (CNC), no exact locality given (Hansen and Klotz 2005).

Camponotus pennsylvanicus (DeGeer) 1773 - 58 . Regina (CNC), no exact locality given (Hansen and Klotz 2005)

Camponotus vicinus Mayr 1870 - 27. Grasslands National Park (UASM), 28. Great Sand Hills (UASM), 72. Val Marie (CNC), no exact locality given (Hansen and Klotz 2005).

\section{Genus Formica}

The genus Formica is widely distributed in the northern hemisphere and is the most speciose genus in Saskatchewan, with 33 confirmed species. Formica are ecologically important in temperate ecosystems, and they are major predators of other insects as well as important food sources for a wide range of organisms, including woodpeckers and bears (Fisher and Cover 2007; Ellison et al. 2012). Within the province, there are six species complexes (the exsecta, fusca, microgyna, neogagates, rufa, and sanguinea groups). Social parasitism is exhibited by sanguinea group species, which are facultative slave-making ants of fusca and neogagates group species (Wheeler and Wheeler 1963, 1986; Fisher and Cover 2007). Microgyna group queens are temporary social parasites of other Formica species (Wheeler and Wheeler 1963, 1986). The record of $F$. accreta at Cree Lake Saskatchewan is a significant northern extension of its known range and is likely an example that more sampling in northern regions is needed to better understand the distributions of ant species. Taxonomically, this genus still needs much work, and there may be several undescribed species in Canada. In Saskatchewan, F. cf. rubicunda is particularly difficult to assess, as some individuals may be easily confused with closely related species, such as $F$. subintegra.

Formica accreta Francoeur 1973 - 11. Cree Lake (UASM).

Formica adamsi Wheeler 1909 - 66. Saskatoon (UofSASK), 72. Val Marie (CNC).

Formica altipetens Wheeler 1913 - Expected but not confirmed: found in Alberta (Glasier et al. 2013) and Manitoba (Wheeler et al. 1989).

Formica argentea Wheeler 1902 - 5. Buffalo Pound Provincial Park (CNC), 10. Clearwater Lake (BDCU), 28. Great Sand Hills (BDCU), 29. Highgate (CNC), 37. Lacadena (Francoeur 1973; CNC), 66. Saskatoon (UofSASK; Francoeur 1973; CNC).

Formica aserva Forel 1901 - 8. Clarine Lake (Kidd and Longair 1997), 11. Cree Lake (UASM), 31. Indian Head (UofSASK), 34. Kamsack (CNC), 39. Love (UofSASK), 42. Methy Lake (Wheeler 1913), 46. Moose Mountain Provincial Park (CNC), 56. Prince Albert National Park (CNC), 66. Saskatoon (UofSASK; CNC), 71. Turtle Lake (CNC), 78. Willows (CNC).

Formica bradleyi Wheeler 1913 - 17. Elbow (CNC), 24. Fox Valley (CNC), 28. Great Sand Hills (UASM), 47. Mortlach (CNC).

Formica canadensis Santschi 1914 - 17. Elbow (Francoeur 1973; CNC), 18. Esterhazy (Francoeur 1973; CNC), 27. Grasslands National Park (PMAE), 28. Great Sand Hills (UASM), 31. Indian Head (Francoeur 1973), 40. Lumsden (Francoeur 1973; CNC), 43. Midale (UofSASK), 66. Saskatoon (Francoeur 1973; CNC).

Formica dakotensis Emery 1893 - 11. Cree Lake (UASM).

Formica densiventris Viereck 1903 - Expected but not confirmed: found in Alberta (Glasier et al. 2013) and Quebec (Francoeur 1977, 2010).

Formica fossaceps Buren 1942 - 61. Rockglen (CNC).

Formica fusca Linnaeus 1758 - 8. Clarine Lake (Kidd and Longair 1997).

Formica glacialis Wheeler 1908 - 1. Aberdeen (CNC), 11. Cree Lake (UASM), 53. Pontrilas (Francoeur 1973; CNC), 73. Wakaw (CNC), 75. Waskesiu Lake (CNC), 77. Willow Bunch (CNC).

Formica hewitti Wheeler 1917 - 11. Cree Lake (UASM), 12. Cypress Hills Interprovincial Park (CNC).

Formica lasioides Emery 1893 - 9. Claydon (CNC), 12. Cypress Hills Interprovincial Park (CNC), 13. 
Delisle (BDCU), 16. Dundurn (CNC), 27. Grasslands National Park (PMAE; UASM), 66. Saskatoon (CNC), 69. Swift Current (CNC).

Formica limata Wheeler 1913 - 10. Clearwater Lake (BDCU), 27. Grasslands National Park (PMAE; UASM), 47. Mortlach (CNC).

Formica microgyna Wheeler 1903 - 27. Grasslands National Park (PMAE; UASM).

Formica montana Wheeler 1910 - 3. Aylesbury (CNC), 10. Clearwater Lake (BDCU), 12. Cypress Hills Interprovincial Park (CNC), 27. Grasslands National Park (PMAE; UASM), 41. Matador (CNC), 66. Saskatoon (CNC).

Formica neoclara Emery 1893 - 10. Clearwater Lake (BDCU), 12. Cypress Hills Interprovincial Park (CNC), 17. Elbow (CNC), 27. Grasslands National Park (PMAE; UASM), 28. Great Sand Hills (UASM), 54. Prelate (BDCU), 58. Regina (UofSASK), 66. Saskatoon (UofSASK).

Formica neogagates Viereck 1903 - 9. Claydon (CNC), 10. Clearwater Lake (BDCU), 16. Dundurn (CNC), 17. Elbow (CNC), 19. Estevan (CNC), 24. Fox Valley (CNC), 27. Grasslands National Park (PMAE; UASM), 28. Great Sand Hills (BDCU; UASM), 46. Moose Mountain Provincial Park (CNC), 66. Saskatoon (CNC).

Formica neorufibarbis Emery 1893 - 11. Cree Lake (UASM), 14. Doremy (CNC), 23. Fort à la Corne (CNC).

Formica obscuripes Forel 1886 - 5. Buffalo Pound Provincial Park (CNC), 9. Claydon (CNC), 10. Clearwater Lake (BDCU), 12. Cypress Hills Interprovincial Park (CNC), 13. Delisle (BDCU), 17. Elbow (CNC), 19. Estevan (CNC), 26. Gainsborough (Weber 1935), 27. Grasslands National Park (PMAE; UASM), 28. Great Sand Hills (BDCU; CNC), 31. Indian Head (CNC), 36. Killdeer (CNC), 44. Minton (CNC), 56. Prince Albert National Park (CNC), 64. Saint Walburg (CNC), 66. Saskatoon (CNC), 69. Swift Current (CNC), 74. Wartime (CNC).

Formica obscuriventris Mayr 1870 - 66. Saskatoon (UofSASK).

Formica obtusopilosa Emery 1893 - 7. Chamberlain (UofSASK), 27. Grasslands National Park (PMAE; UASM), 60. Robsart (CNC).

Formica oreas Wheeler 1903 - 10. Clearwater Lake (BDCU), 17. Elbow (CNC), 56. Prince Albert National Park (UofSASK), 66. Saskatoon (UofSASK; $\mathrm{CNC})$, 69. Swift Current (CNC).

Formica pergandei Emery 1893 - 47. Mortlach (CNC).

Formica perpilosa Wheeler 1913 - 27. Grasslands National Park (UASM), 77. Willow Bunch (CNC).

Formica planipilis Creighton 1940 - 52. Pike Lake (UofSASK), no exact locality given but is listed by Wheeler and Wheeler (1986).

Formica podzolica Francoeur 1973 - 5. Buffalo Pound Provincial Park (CNC), 6. Canora (CNC), 12.
Cypress Hills Interprovincial Park (CNC), 13. Delisle (BDCU), 32. Jay Lake (CNC), 33. Junction Reservoir (PMAE), 38. Laura (CNC), 45. Montmartre (CNC), 46. Moose Mountain Provincial Park (CNC), 51. Pasqua (CNC), 56. Prince Albert National Park (CNC), 66. Saskatoon (UofSASK; CNC), 71. Turtle Lake (CNC), 77. Willow Bunch (CNC).

Formica puberula Emery 1893 - 66. Saskatoon (CNC).

Formica ravida Creighton 1940 - 11. Cree Lake (UASM).

Formica cf. rubicunda Emery 1893 - 27. Grasslands National Park (PMAE).

Formica spatulata Buren, 1944 - 51. Pasqua (CNC). Formica subaenescens Emery 1893 - 56. Prince Albert National Park (CNC).

Formica subintegra Wheeler 1908 - Expected but not confirmed: found in Alberta (Glasier et al. 2013) and Manitoba (Wheeler et al. 1989).

Formica ulkei Emery 1893 - 19. Estevan (CNC), 35. Kenosee Lake (CNC).

\section{Genus Lasius}

Lasius is the second most speciose genus in Saskatchewan, with 14 confirmed species. Most species are omnivorous and many have close associations with above and/or below ground homopterans (Newton et al. 2011). There are four main species complexes: claviger, flavus, niger, and umbratus groups. All claviger and umbratus group queens exhibit temporary social parasitism on other Lasius species (Wilson 1955; Wing 1968; Fisher and Cover 2007). Because of the subterranean nature of many Lasius ants, they can be rather difficult to find; however, other species, such as $L$. neoniger are common and can often be found making "volcanoes" or cone-shaped mounds along sidewalks or in sandy areas. There is a debate about whether some Lasius species have a true holarctic distribution or if they might have been introduced in North America; more work is needed to resolve this discussion.

Lasius alienus (Förster) 1850 - 16. Dundurn (CNC), 66. Saskatoon (CNC).

Lasius coloradensis Wheeler 1917 - 27. Grasslands National Park (PMAE), 60. Robsart (CNC), 66. Saskatoon (CNC; UofSASK), no exact locality given, on map only (Wing 1968).

Lasius crypticus Wilson 1955 - 3. Aylesbury (CNC), 5. Buffalo Pound Provincial Park (CNC), 9. Claydon (CNC), 11. Cree Lake (UASM), 19. Estevan (CNC), 27. Grasslands National Park (PMAE;UASM), 28. Great Sand Hills (BDCU; UASM), 61. Rockglen (CNC), 77. Willow Bunch (CNC), no exact locality given, on map only (Wilson 1955).

Lasius fallax Wilson 1955 - 66. Saskatoon (Uof SASK).

Lasius flavus (Fabricius) 1781 - 5. Buffalo Pound Provincial Park (CNC), 21. Farewell Lake (Wilson, 1955), 66. Saskatoon (CNC). 
Lasius interjectus Mayr 1866 - 66. Saskatoon (CNC). Lasius latipes (Walsh) 1863 - 28. Great Sand Hills (UASM).

Lasius murphyi Forel 1901 - No exact locality given, on map only (Wing 1968).

Lasius neoniger Emery 1893 - 4. Beaver Creek (CNC), 19. Estevan (CNC), 27. Grasslands National Park (PMAE; UASM), 28. Great Sand Hills (UASM), 31. Indian Head (UofSASK; CNC), 33. Junction Reservoir (PMAE). 66. Saskatoon (CNC), 70. Truax (UofSASK), no exact locality given, on map only (Wilson 1955).

Lasius niger (Linnaeus) 1758 - 77. Willow Bunch (CNC).

Lasius occidentalis Wheeler W. M. 1909 - Expected but not confirmed: found in British Columbia and Manitoba (Wing 1968).

Lasius pallitarsis (Provancher) 1881 - 4. Beaver Creek (CNC), 5. Buffalo Pound Provincial Park (CNC), 10. Clearwater Lake (BDCU), 13. Delisle (BDCU), 27. Grasslands National Park (PMAE; UASM), 38. Laura (CNC), 45. Montmartre (CNC), 65. Saskatchewan Landing Provincial Park (CNC), 66. Saskatoon (UofSASK; CNC), 69. Swift Current (CNC), no exact locality given, on map only (Wilson 1955).

Lasius subglaber Emery 1893 - 66. Saskatoon (CNC), no exact locality given, on map only (Wing 1968).

Lasius subumbratus Viereck 1903 - 27. Grasslands National Park (PMAE; UASM), 40. Lumsden (CNC), 58. Regina (CNC; Wilson 1955).

Lasius umbratus (Nylander) 1846 - 3. Aylesbury (CNC), 5. Buffalo Pound Provincial Park (CNC), 19. Estevan (CNC), 22. Flintoft (CNC), 27. Grasslands National Park (PMAE), 66. Saskatoon (CNC), 77. Willow Bunch (CNC).

\section{Genus Polyergus}

Polyergus mexicanus is the only species of its genus reported in Saskatchewan. This species is an obligate slave-making ant, parasitizing fusca group Formica species (Trager 2013). Polyergus are easily recognized by their toothless, sickle-shaped mandibles, which are highly adapted for fighting other ants.

Polyergus mexicanus Forel 1899 - 11. Cree Lake (UASM).

\section{Subfamily Myrmicinae}

Genus Formicoxenus

Formicoxenus are small and live within the nests of Formica or Myrmica (Francoeur et al. 1985). They rely on their hosts for food and protection, but often construct side chambers where they keep their own larvae (Francoeur et al. 1985). As they live in the nests of other ants, Formicoxenus can often be difficult to detect using regular sampling methods. To find these small reddish-brown ants, it is often best to sift the soil of a potential host colony, using a strainer or sieve. They look similar to Leptothorax and Temnothorax, but have erect setae on their eyes, a characteristic that can be detected only by using a microscope.

Formicoxenus hirticornis (Emery) 1895 - Expected but not found: found in Alberta (Glasier et al. 2013) and Manitoba (Wheeler et al. 1989).

Formicoxenus quebecensis Francoeur 1985 - 11. Cree Lake (UASM).

Formicoxenus provancheri (Emery) 1895 - Expected but not confirmed: found in Alberta (Francoeur et al. 1985; Glasier et al. 2013; Glasier and Acorn 2014), Ontario, and Quebec (Francoeur et al. 1985).

\section{Genus Harpagoxenus}

Harpagoxenus is an obligate slave-making ant of Leptothorax species (Stuart and Alloway 1983). The only species in Canada, $H$. canadensis Smith primarily enslaves Leptothorax species. These ants are similar in size to Leptothorax and Temnothorax, but have toothless mandibles and large block-like heads.

Harpagoxenus canadensis Smith 1939 - Expected but not confirmed: found in Alberta (Glasier et al. 2013), Ontario (Stuart and Alloway 1983), and Quebec (Francoeur 1977).

\section{Genus Leptothorax}

Species in the genus Leptothorax are difficult to identify confidently without comparative material and much familiarization (Fisher and Cover 2007; Glasier et al. 2013). They are common in a wide range of habitats and often nest in rotten wood or under stones. Leptothorax acervorum (Fabricius) 1793 - Expected but not confirmed: found in Yukon (Francoeur 1997), Manitoba, and Quebec (Francoeur 1983).

Leptothorax muscorum (Nylander) 1846 - 4. Beaver Creek (CNC), 8. Clarine Lake (Kidd and Longair 1997), 11. Cree Lake (UASM), 15. Dunblane (CNC), 17. Elbow (CNC), 27. Grasslands National Park (PMAE), 31. Indian Head (CNC), 47. Mortlach (CNC), 66. Saskatoon (CNC).

Leptothorax retractus Francoeur 1986 - 66. Saskatoon $(\mathrm{CNC})$.

Leptothorax wilsoni Heinze 1989 - Expected but not confirmed: found in Alberta (Buschinger and Schumann 1994), Quebec, and New Brunswick (Heinze 1989).

\section{Genus Monomorium}

Monomorium minimum is a wide-ranging species complex found across most of North America (Fisher and Cover 2007). It is often found under rocks or in rotting wood. Monomorium pharaonis is an introduced ant that is primarily found in heated buildings (Klotz et al. 2008). Both species are small, have colonies of a few thousand workers, often move nest sites, and have multiple queens per colony (Wheeler and Wheeler 1963, 1986). 
Monomorium minimum (Buckley) 1867 - 10. Clearwater Lake (BDCU), 27. Grasslands National Park (PMAE; UASM).

Monomorium pharaonis (Linnaeus) 1758 - Expected but not confirmed: an introduced species found across North America and expected in human dwellings (Klotz et al. 2008). Found in Alberta (Glasier et al. 2013), Manitoba (Ayre 1977), Quebec (Francoeur 1977), British Columbia, Nunavut, Ontario, and Nova Scotia (LHB, unpublished observation).

\section{Genus Myrmica}

Identification of Myrmica species can be difficult, as many species are distinguished by few or obscure characteristics (Fisher and Cover 2007; Ellison et al. 2012; Glasier et al. 2013). They are common throughout Saskatchewan and are found in most ecoregions. Myrmica are generalist omnivores that hunt insects, harvest plant materials, and farm homopterans (Fisher and Cover 2007; Newton et al. 2011). Taxonomically, this genus is still in need of more work in North America (Fisher and Cover 2007; Jansen et al. 2010), and the two undescribed species (Myrmica AF-eva and Myrmi$c a$ cf. AF-sub) highlight this lack of understanding.

Myrmica alaskensis Wheeler 1917 - 1. Aberdeen (CNC), 11. Cree Lake (UASM), 57. Quill Lake (UofSASK), 66. Saskatoon (CNC).

Myrmica americana Weber 1939 - 17. Elbow (CNC), 27. Grasslands National Park (PMAE; UASM), 47. Mortlach (CNC).

Myrmica brevispinosa Wheeler 1917 - 16. Dundurn (CNC), 31. Indian Head (CNC), 25. Gabriel's Bridge (South Saskatchewan River) (CNC), 27. Grasslands National Park (PMAE; UASM), 28. Great Sand Hills (UASM), 66. Saskatoon (UofSASK), 69. Swift Current (CNC).

Myrmica crassirugis Francoeur 2007 - 27. Grasslands National Park (PMAE; UASM), 28. Great Sand Hills (UASM).

Myrmica detritinodis Emery 1921 - 2. Atton's Lake (CNC), 11. Cree Lake (UASM), 66. Saskatoon (CNC).

Myrmica fracticornis Forel 1901 - 2. Atton's Lake (CNC), 3. Aylesbury (CNC), 5. Buffalo Pound Provincial Park (CNC), 6. Canora (CNC), 8. Clarine Lake (Kidd and Longair 1997), 11. Cree Lake (UASM), 17. Elbow (CNC), 31. Indian Head (CNC), 47. Mortlach (CNC), 56. Prince Albert National Park (UofSASK), 66. Saskatoon (CNC).

Myrmica incompleta Provancher 1881 - 12. Cypress Hills Interprovincial Park (CNC), 30. Humbolt Lake (CNC), 31. Indian Head (CNC), 38. Laura (CNC), 41. Matador (CNC), 56. Prince Albert National Park (CNC), 66. Saskatoon (CNC; UofSASK), 71. Turtle Lake (CNC), 75. Waskesiu Lake (CNC).

Myrmica latifrons Stärcke 1927 - 2. Atton's Lake (CNC), 4. Beaver Creek (CNC), 27. Grasslands National Park (PMAE; UASM), 32. Jay Lake (CNC),
38. Laura (CNC), 45. Montmartre (CNC), 47. Mortlach (CNC), 66. Saskatoon (UofSASK).

Myrmica lobifrons Pergande 1900 - Expected but not confirmed: found in British Columbia (Higgins and Lindgren 2008), Yukon (Francoeur 1977), Alberta (Glasier et al. 2013), Manitoba, Ontario, New Brunswick, and Newfoundland and Labrador (LHB, unpublished observation).

Myrmica nearctica Weber 1939 - 68. Success (UofSASK).

Myrmica undescribed code AF-eva by André Francoeur - 19. Estevan (CNC), 27. Grasslands National Park (PMAE; UASM), 28. Great Sand Hills (UASM), 38. Laura (CNC), 60. Robsart (CNC).

Myrmica cf. undescribed code AF-sub by André Francoeur - 11. Cree Lake (UASM).

\section{Genus Pogonomyrmex}

Pogonomyrmex species are commonly called harvester ants, as they harvest and eat seeds of grasses and other plants (Fisher and Cover 2007). P. occidentalis colonies also construct obvious cone-shaped nests, often covered with small stones, which makes them easily visible from many metres away.

Pogonomyrmex occidentalis (Cresson) $1865-28$. Great Sand Hills (CNC; UASM).

\section{Genus Solenopsis}

Solenopsis molesta is the only species in the genus Solenopsis in the province, and it is part of a species complex that is found throughout North America (Fisher and Cover 2007). These ants are often called thief ants, for their tendency to nest near larger ants from which they "steal" stored food (Fisher and Cover 2007). Solenopsis molesta (Say) 1836 - 20. Eston (CNC),

27. Grasslands National Park (PMAE; UASM).

\section{Genus Stenamma}

Stenamma diecki is found in southern forests of other Canadian provinces and may be found in southern woodlands, such as the Cypress Hills, in Saskatchewan. This species forages individually, prefers moist soils, and will feign death for a short time when disturbed, making it difficult to detect (Talbot 1976).

Stenamma diecki Emery 1895 - Expected but not confirmed: found in British Columbia (Higgins and Lindgren 2008), Ontario (Smith 1957), Quebec (Francoeur 1977), and New Brunswick (LHB, unpublished observation).

\section{Genus Temnothorax}

The two species of Temnothorax in Saskatchewan are often found in grassland habitats. These ants forage alone, are cautious of other ants, and are opportunistic feeders, eating anything from plant sap to invertebrates (Fisher and Cover 2007; Newton et al. 2011).

Temnothorax ambiguus (Emery) 1895 - 27. Grasslands National Park (PMAE; UASM), 66. Saskatoon $(\mathrm{CNC})$. 
Temnothorax rugatulus (Emery) 1895 - 27. Grasslands National Park (PMAE;UASM), 72. Val Marie (UofSASK).

\section{Subfamily Ponerinae \\ Genus Hypoponera}

Hypoponera punctatissima is an introduced ant species found worldwide (Bolton and Fisher 2011), in Canada primarily in heated buildings. It has been found across Canada (LHB, unpublished observation) and is likely found in Saskatchewan (Klotz et al. 2008).

Hypoponera punctatissima (Roger) 1859 - Expected but not confirmed: in Canada, found in Quebec (Francoeur 1977), Alberta (JHA, unpublished observation), Ontario, and British Columbia (LHB, unpublished observation).

\section{Acknowledgements}

We thank Cedric Gillot and Art Davis at the University of Saskatchewan; Andrew Bennett, Hymenoptera curator, Canadian National Collection of Insects, Arachnids and Nematodes; John Swann, manager of the Insects \& Invertebrate Zoology Museum at the University of Calgary; Felix Sperling and Danny Schpeley at the E. H. Strickland Entomological Museum, University of Alberta; and Matthias Buck, assistant curator, Invertebrate Zoology at the Royal Alberta Museum for providing access to their Formicidae collections. David Eldridge at the University of New South Wales provided helpful comments on an early draft of the manuscript.

\section{Literature Cited}

Ayre, G. L. 1977. Exotic ants in Winnipeg. Manitoba Entomologist 11: 42-44.

Bolton, B., and B. L. Fisher. 2011. Taxonomy of Afrotropical and West Palaearctic ants of the ponerine genus Hypoponera Santschi (Hymenoptera: Formicidae). Zootaxa 2843: 1-118.

Buschinger, A., and R. D. Schumann. 1994. New records of Leptothorax wilsoni from western North America. Psyche 101: 13-18.

Chikoski, J. M., S. H. Ferguson, and L. Meyer. 2006. Effects of water addition on soil arthropods and soil characteristics in a precipitation-limited environment. Acta Oecologica 30: 209-211.

Ellison, A. M., N. J. Gotelli, E. J. Farnswoth, and G. Alpert. 2012. A Field Guide to the Ants of New England. Yale University Press, New Haven, Connecticut, USA.

Ferguson, S. H. 2000. Predator size and distance to edge: is bigger better? Canadian Journal of Zoology 78: 713-720.

Ferguson, S. H. 2001. Changes in trophic abundance of soil arthropods along a grass-shrub-forest gradient. Canadian Journal of Zoology 79: 457-464.

Ferguson, S. H. 2004. Influence of edge on predator-prey distribution and abundance. Acta Oecologica 25: 111-117.

Fisher, B. L., and S. P. Cover. 2007. Ants of North America: A Guide to the Genera. University of California Press, Los Angeles, California, USA.

Francoeur, A. 1973. Revision taxonomique des espèces néarctiques du groupe Fusca, genre Formica (Formicidae,
Hymenoptera). Memoires de la Société Entomogique du Québec 3: 1-316.

Francoeur, A. 1977. Synopsis taxonomique et économique des fourmis du Québec (Formicidae, Hymenoptera). Annals of the Entomological Society of Québec 22: 205-212.

Francoeur, A. 1983. The ant fauna near the tree-line in northern Québec (Formicidae, Hymenoptera). Collection Nordicana 47: $177-180$.

Francoeur, A. 1986. Deux nouvelles fourmis Neartiques: Leptothorax retractus et L. sphagnicolus (Formicidae, Hymenoptera). Canadian Entomologist 118: 1151-1164.

Francoeur, A. 1997. Ants (Hymenoptera: Formicidae) of the Yukon. Biological Survey of Canada Monograph Series 2: 901-910.

Francoeur, A. 2010. Liste des espèces de fourmis (Formicides, Hyménoptères). Entomofaune du Québec, Saguenay, Quebec, Canada. Accessed 29 December 2014. http://ento mofaune.qc.ca/Feuillets/DF01-formicides_v5.pdf.

Francoeur, A., R. Loiselle, and A. Buschinger. 1985. Biosystématique de la tribu Leptothoracini (Formicidae, Hymenoptera). 1. Le genre Formicoxenus dans la région holarctique. Le Naturaliste Canadien 112: 343-403.

Glasier, J. R. N., and J. H. Acorn. 2014. Annotated list of ants (Hymenoptera: Formicidae) from the grasslands of Alberta and Saskatchewan. Pages 299-314 in Arthropods of Canadian Grasslands. Volume 4: Biodiversity and Systematics, Part 2. Edited by D. J. Giberson and H. A. Cárcamo. Biological Survey of Canada.

Glasier, J. R. N., J. H. Acorn, S. E. Nielsen, and H. Proctor. 2013. Ants (Hymenoptera: Formicidae) of Alberta: a key to species based primarily on the worker caste. Canadian Journal of Arthropod Identification 22: 1-104.

Hansen, L. D., and J. H. Klotz. 2005. The Carpenter Ants of the United States and Canada. Cornell University Press, Ithaca, New York, USA.

Heinze, J. 1989. Leptothorax wilsoni n. sp., a new parasitic ant from eastern North America (Hymenoptera: Formicidae). Psyche 96: 49-62.

Higgins, R. J., and B. S. Lindgren. 2008. Ants of British Columbia (Hymenoptera: Formicidae). Accessed 29 December 2014. http://www.geog.ubc.ca/biodiversity/efauna/doc uments/AntsofBCHigginsLIndgren2008.pdf.

Jansen, G., R. Savolainen, and K. Vepsäläinen. 2010. Phylogeny, divergence-time estimation, biogeography and social parasite-host relationships of the Holarctic ant genus Myrmica (Hymneoptera: Formicidae). Molecular Phylogenetics and Evolution 56: 294-304.

Kidd, M. G., and R. W. Longair. 1997. Abundance and diversity of ant (Hymenoptera: Formicidae) assemblages in regenerating forests of northern Saskatchewan. Canadian Field-Naturalist 111: 635-637.

Klotz, J., L. Hansen, R. Pospischil, and M. Rust. 2008. Urban Ants of North America and Europe. Cornell University Press, Ithaca, New York, USA.

Mackay, W. P. 1993. A review of the New World ants of the genus Dolichoderus (Hymenoptera: Formicidae). Sociobiology 22: 1-148.

Mackay, W. P., and E. Mackay. 2002. The Ants of New Mexico: (Hymenoptera: Formicidae). Edwin Mellen Press, Lewiston, New York, USA.

Newton, J. S., J. Glasier, H. E. L. Maw, H. C. Proctor, and R. G. Foottit. 2011. Ants and subterranean Sternorrhyncha in a native grassland in east-central Alberta. Canadian Entomologist 143: 518-523. 
Radtke, T. M., J. R. N. Glasier, and S. D. Wilson. 2014. Species composition and abundance of ants and other invertebrates in stands of crested wheatgrass (Agropyron cristatum) and native grasslands in the northern Great Plains. Canadian Journal of Zoology 92: 49-55.

Saskatchewan Conservation Data Centre. 2014. Saskatchewan's ecoregions. Saskatchewan Conservation Data Centre, Fish and Wildlife Branch, Saskatchewan Ministry of Environment, Regina, Saskatchewan, Canada. Accessed 29 December 2014. http://www.biodiversity.sk.ca/eco.htm.

Smith, M. R. 1957. Revision of the genus Stenamma Westwood in America north of Mexico (Hymenoptera, Formicidae). American Midland Naturalist 57: 133-174.

Stuart, R. J. and T. M. Alloway. 1983. The slave-making ant Harpagoxenus canadensis M. R. Smith, and its hostspecies Leptothorax muscorum (Nylander): slave raiding and territoriality. Behaviour 85: 58-90.

Talbot, M. 1976. Habitats and populations of the ant Stenamma diecki Emery in southern Michigan. Great Lakes Entomologist 8: 241-244.

Trager, J. C. 2013. Global revision of the dulotic ant genus Polyergus (Hymenoptera: Formicidae, Formicinae, Formicini). Zootaxa 3722: 501-548.

Weber, N. A. 1935. The biology of the thatching ant, Formica rufa obscuripes Forel, in North Dakota. Ecological Monographs 5: 165-206.
Wheeler, G. C., and J. Wheeler. 1963. The Ants of North Dakota. University of North Dakota Press, Grand Forks, North Dakota, USA.

Wheeler, G. C., and J. Wheeler. 1977. North Dakota Ants Updated. Desert Research Institute, University of Nevada System, Reno, Nevada, USA.

Wheeler, G. C., and J. N. Wheeler. 1986. The Ants of Nevada. Natural History Museum of Los Angeles County, Los Angeles, California, USA.

Wheeler, G. C., and J. Wheeler. 1988. A checklist of ants of Montana. Psyche 95: 101-114.

Wheeler, G. C., J. Wheeler, T. D. Galloway, and G. L. Ayre. 1989. A list of ants of Manitoba. Proceedings of the Entomological Society of Manitoba 45: 34-49.

Wheeler, W. M. 1913. A revision of the ants of the genus Formica (Linné) Mayr. Bulletin of the Museum of Comparative Zoology 53: 379-565.

Wilson, E. O. 1955. A monographic revision of the ant genus Lasius. Bulletin of the Museum of Comparative Zoology 113: 1-201.

Wing, M. W. 1968. Taxonomic Revision of the Nearctic Genus Acanthomyops (Hymenoptera: Formicidae). Memoir 405. Cornell University Agricultural Experiment Station, New York State College of Agriculture, Ithaca, New York, USA.

Received 20 April 2015

Accepted 9 November 2015 